\title{
AN UNCOMMON PRESENTATION: 66 YEAR-OLD WOMAN WITH A TUMOR-LIKE MEDIAL MENISCAL CYST - A CASE REPORT
}

doi: 10.1590/S1807-59322008000300022

Giovannini Cesar Figueiredo, Evânia Claudino Queiroga de Figueiredo, Ericsson Albuquerque Marques

\section{INTRODUCTION}

Meniscal cysts are well-defined and documented lesions that were first reported by Nicaise in 1883 (according to Kurian, 2003 $)^{1}$ and are located adjacent to the peripheral margin of the meniscus. They are almost always associated with a meniscal tear. ${ }^{2}$ Even though Barrie $^{3}$ reported meniscal cysts in up to $7 \%$ of patients undergoing meniscectomy, others have stated that the true prevalence is probably about $1 \%$ of patients who undergo meniscectomy ${ }^{4}$. In addition, while some authors have advocated that lateral meniscal cysts are three to ten times more common than medial cysts ${ }^{5}$, others have stated that medial cysts are more frequent $t^{6 ; 7}$. Meniscal cysts are most often seen in young adults and occur more frequently in men than women. ${ }^{8}$

\section{CASE REPORT}

A 66-year-old woman had a history of mild pain in the left knee that had increased in severity over six months. There was no history of trauma. On examination, the patient had pain in the medial aspect of the joint line, with focal tissue swelling on the medial aspect of the knee. The swelling was large (Figure 1) and painful, but the knee did not lock or give way. On physical examination, a consistent and large, orange-sized mass could be seen and palped. Lachman's, McMurray's, and Apley's tests were negative, and the range of motion was $0-110^{\circ}$. Magnetic resonance showed that the mass was multi-lobulated with thin septations and surrounded the medial collateral ligament (Figures 2, 3, 4). Through a medial arthrotomy (Figure 5),

State University of Paraíba, Orthopedic Clinics - Campina Grande/PB, Brazil.

giocesar@uol.com.br

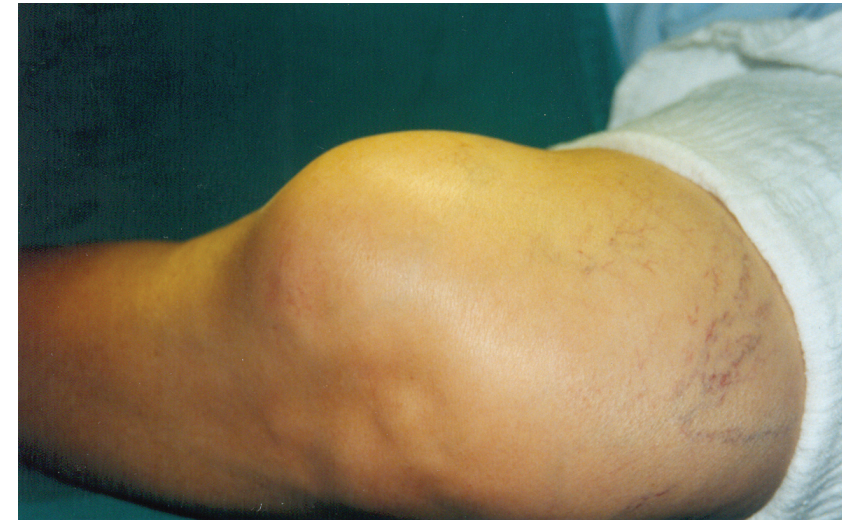

Figure 1 - External aspect of the cyst

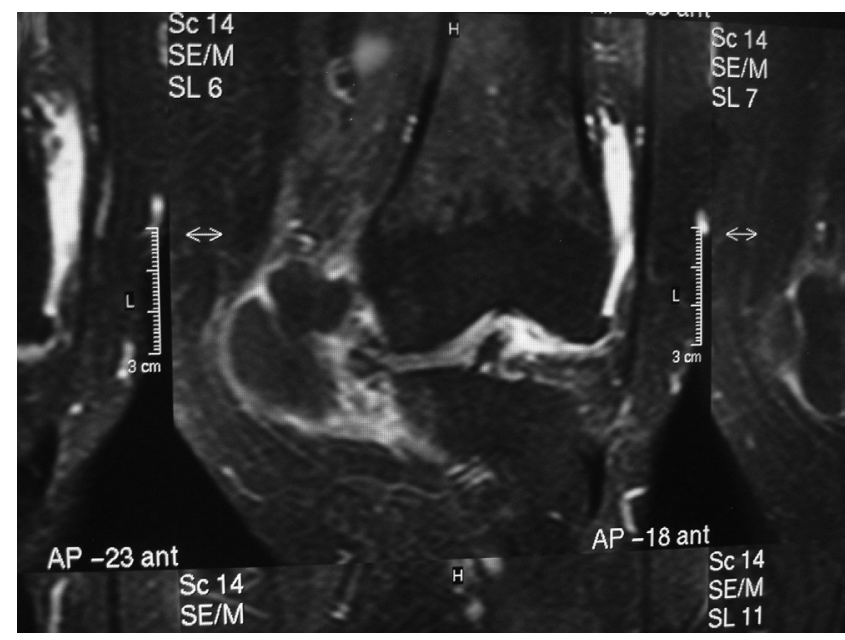

Figure 2 - T1 coronal view

the cyst was excised intact with its correspondent meniscus (Figure 6). The specimen measured 50 x 40 x $40 \mathrm{~mm}$ and contained clear gelatinous material. A split retinacular graft was performed to fulfil the capsule failure. Histological examination showed chronic inflammation without 


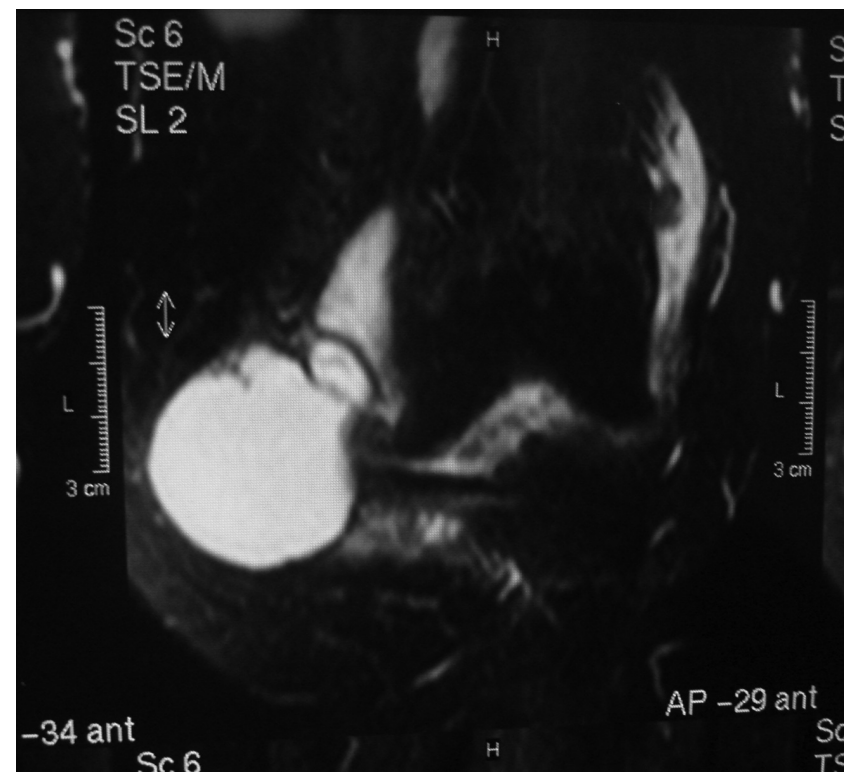

Figure 3 - T2 coronal view

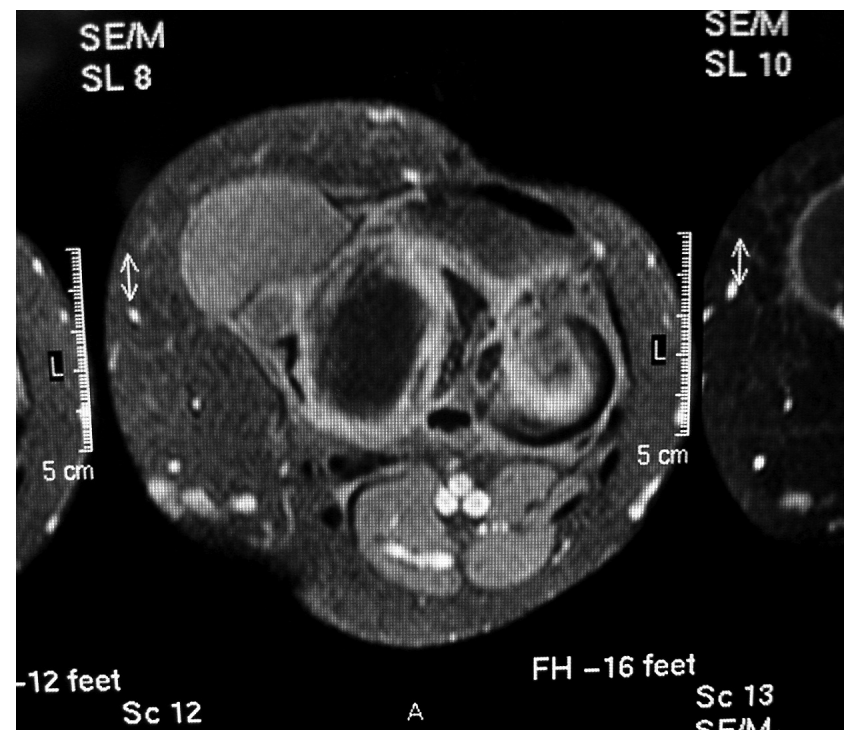

Figure 4 - T1 axial view

malignancy. The patient was ordered to wear a brace with partial weight bearing for two weeks. Rehabilitation occurred uneventfully. After a 2-year follow-up, the patient had full range of articular motion with no recurrence.

\section{DISCUSSION}

The etiology of meniscal cysts is controversial. Many authors advocate that trauma, chronic infection, hemorrhage, and mucoid degeneration may lead to the development of these entities 9 . Because the fluid found in meniscal cysts is similar to sinovial fluid, the prevailing view is that cysts form from joint fluid that is forced through a peripherally extended

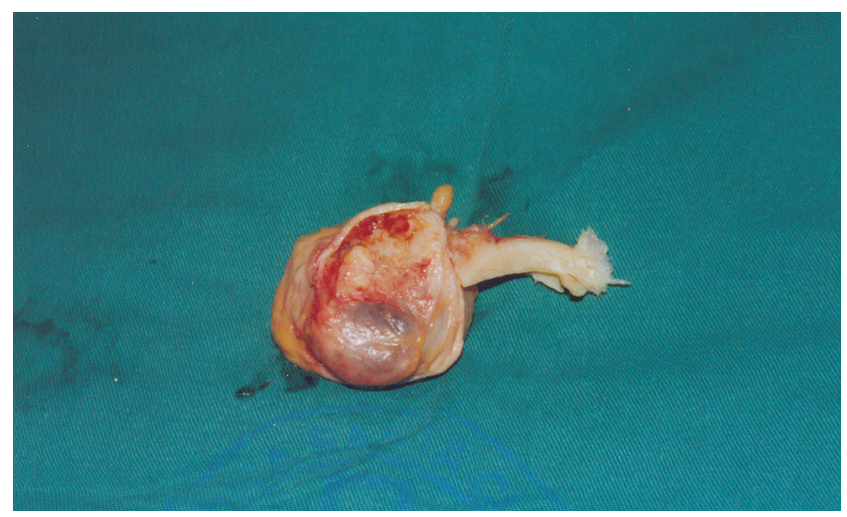

Figure 6 - Resected cyst with medial meniscus

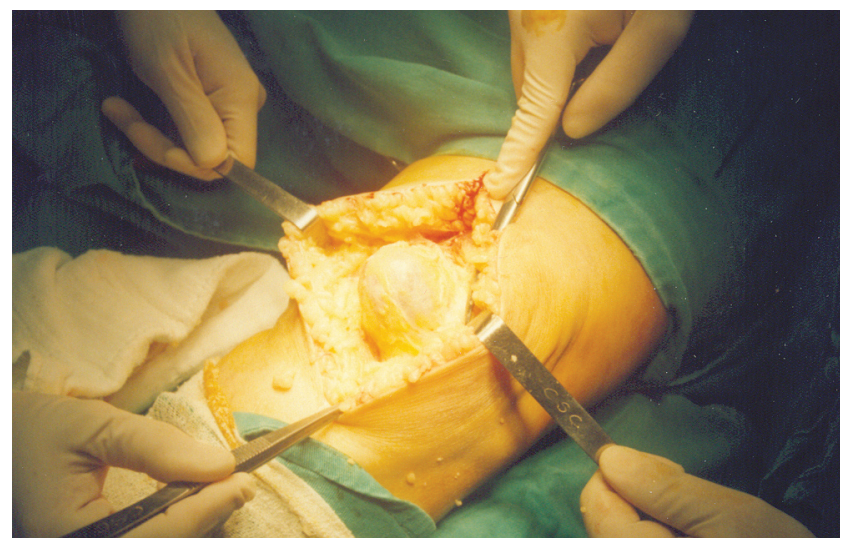

Figure 5 - Cyst resection using the open approach

meniscal tear and accumulates outside the joint capsule ${ }^{10}$. Pain is most likely related to the associated meniscal tears, but discomfort may also be due to stretching of the knee capsule and other parameniscal soft tissues ${ }^{11}$. The mass may be multiloculate and demonstrate thin internal septations, and its consistency may vary from soft and fluctuant to firm or bone-hard. MRI is preferred for evaluating meniscal cysts $^{6,12}$ because it shows structures such as the menisci, cartilage and ligaments and is the most effective modality to evaluate soft-tissue masses. The differential diagnosis for soft-tissue masses of the knee should include sinovial cyst formation, bursal fluid collections, ganglion cysts, severe degenerative changes with osteophytic spurring and soft-tissue masses such as pigmented villonodular sinovitis, lipoma, hemangioma and sarcomas9. Meniscal cysts tend to recur after aspiration or simple resection ${ }^{6}$. Therefore, open or arthroscopic intra-articular surgery to treat the underlying meniscal tear is necessary for successful therapy ${ }^{13-15}$. In conclusion, distinguishing meniscal cysts from other cystic lesions is important because meniscal cysts more often require surgery. In our case, the uncommon combination of mass size and location associated with the gender and age of the host led us to report it. 


\section{REFERENCES}

1. Kurian J, Schindler OS, Hussain A. Medial meniscal cyst of the knee. An unusual presentation: a case report. J Orthop Surg. 003;11:234-6.

2. Lu KH. Arthroscopic meniscal repair and needle aspiration for meniscal tear with meniscal cyst. Arthroscopy. 2006;22:1367, E1-4.

3. Barrie HJ. The pathogenesis and significance of meniscal cysts. J Bone Joint Surg. 979;61:184-9.

4. Mills CA, Henderson IJ. Cysts of the medial meniscus; arthroscopic diagnosis and management. J Bone Joint Surg. 1993;75:293-8.

5. Niceforo A, Di Giunta AC, Caminiti S, Tirro S. A rare case of a large lateral meniscal cyst of the knee. Arthroscopy. 1998;14:759-61.

6. Burk Dl, Dalinka MK, Kanal E, Schiebler ML, Cohen EK, Prorok RJ, et al. Meniscal and ganglion cysts of the knee: MR evaluation. Am J Roentgenol. 988;150:331-6.

7. Tasker AD, Ostlere SJ. Relative incidence and morphology of lateral and medial meniscal cysts detected by magnetic resonance imaging. Clin Radiol. 995;50:778-81.

8. Lantz B, Singar KH. Meniscal cysts. Clin Sports Med. 1990;9:707-25
9. Ryu RK, Ting AJ. Arthroscopic treatment of meniscal cysts. Arthroscopy 1993;9:591-5.

10. Janzen DL, Peterfy CG, Forbes JR, Tirman PF, Genen HK. Cystic lesions around the knee joint: MR imaging findings. Am J Roentgenol. 1994;163:155-61.

11. Tyson LL, Daughters TC Jr, Ryu RK, Crues JV $3^{\text {rd }}$. MRI appearance of meniscal cysts. Skeletal Radiol. 1995;24:421-4.

12. Campbell SE, Sanders TG, Morrison WB. MR imaging of meniscal cysts: incidence, location, and clinical significance. Am J Roentgenol. 2001;177:409-13

13. Hulet C, Souquet D, Alexandre P, Locker B, Beguin J, Vielpeau C. Arthroscopic treatment of 105 lateral meniscal cysts with 5-year average follow-up. Arthroscopy. 2004;20:831-6.

14. Reagan WD, McConkey JP, Loomer R1, Davidson RG. Cysts of the lateral meniscus: arthroscopy versus arthroscopy plus open cystectomy. Arthroscopy. 1989;5:274-81.

15. El-Assal M, Mostafa M, Andel-Aal A, El-Shafee M. Arthroscopy alone or in association with open cystectomy: in treatment of lateral meniscal cysts. Knee Surg Sports Traumatol Arthrosc. 2003;11:30-2. 